\title{
ENTREPRENEURIAL ATTITUDES AND THE LEVEL OF INNOVATIVENESS OF EUROPEAN COUNTRIES
}

\author{
Wojciech Truszkowski ${ }^{1}, \mathrm{PhD}$; Anna Strychalska-Rudzewicz ${ }^{2}, \mathrm{PhD}$ \\ ${ }^{1}$ Department of Environmental Management and Agriculture, University of Warmia and Mazury in Olsztyn, \\ Poland; ${ }^{2}$ Department of Business Economics, University of Warmia and Mazury in Olsztyn, Poland
}

\begin{abstract}
This paper analysed the relations between entrepreneurial attitudes among the citizens of European countries and the results of economies in the field of innovativeness. Data published in the Global Entrepreneurship Monitor (GEM) and European Innovation Scoreboard (EIS) were used to assess these relations. It was demonstrated that the citizens of countries witha higher innovativeness ratio demonstrate weaker entrepreneurial intentions (intensions to start a business within three years). Paradoxically, in more innovative countries, in spite of a stronger perception of opportunities to start a new firm, weaker intentions to start a business are also observed, which may result from greater attractiveness of remunerated employment as well as a more critical assessment of their skills and knowledge of starting a business.
\end{abstract}

Key words: entrepreneurial attitudes, innovativeness, European countries.

JEL code: 031.

\section{Introduction}

According to subject-related literature, innovativeness is strictly connected with entrepreneurship (Glinka B., 2008, Domurat A., 2011). The crucial role of cultural factors, including entrepreneurial attitudes, is particularly emphasized in establishing innovativeness (Gupta V. et. al., 2004, GomezHaro S. et al., 2011). The relationship between entrepreneurial attitudes and the innovativeness of economies results from the importance of these cultural attitudes, potentially influencing the possibility to motivate the entire society to innovativeness and inventiveness in order to create an innovative society (Kwiatkowski S., 2000). It can be claimed that culture supports and preserves entrepreneurial activities within an organization and combines entrepreneurial behaviours while searching for occasions to bring innovations to life (Dimitratos P. et. al., 2012). In this way, the culture emphasizing and supporting entrepreneurial efforts influences the quality and quantity of innovation at a national level (Baker W., Sinkula J., 1999; Wai H., YeungC., 2002). This results from the fact that an environment encouraging entrepreneurship may motivate an individual to creativity, and shape their entrepreneurial style of functioning.

The literature quoted provides numerous justifications confirming the thesis on positive relations between entrepreneurship and innovativeness. However, there are No studies emphasizing the relationships between entrepreneurial attitudes and the innovativeness of countries. Due to the research gap in this field, the purpose of the paper was formulated, i.e. studying the relations between entrepreneurial attitudes of the citizens of European countries and the results of economies in the field of innovativeness measured with the SII value. Due to geographical proximity and cultural resemblance (European civilization circle), the present article concentrated on an analysis of relations between the studied variables in European countries.

In the research were formulated certain tasks. The first task of this research was to collect data concerning entrepreneurial attitudes of the citizens of European countries published in the Global Entrepreneurship Monitor (GEM). The second task was to assemble data concerning innovativeness of countries published by European Innovation Scoreboard (EIS). Then, as the third task, to analyse the relations between entrepreneurial attitudes among the citizens of European countries and the results of economies in the field of innovativeness. 


\section{Research results and discussion}

Economic analyses treat entrepreneurship as a phenomenon with an exclusively economic character, in which major rolesare played by: capital, labour supply, access to markets, resources and technology (Glinka B., 2008; Berger B., 1994). The mainstream of economic studies (neo-Classic approach) is based on the axiom of a rational individual (homo oeconomicus), who aims at maximizing profits. Many times, analyses referring to the cultural context of entrepreneurship are marginalized (Glinka B., 2008). Full understanding of the phenomenon of entrepreneurship should take into account cultural factors, which may constitute support for entrepreneurial activities or impede them. Cultural explanations are usually quoted when other, "harder" variables fail (Marody M., Kochanowicz J., 2010). The ways of thinking about entrepreneurship, attitudes towards entrepreneurs as well as the forms in which they are manifested are strongly rooted in the cultural context. This context suggests certain ideas and concepts of entrepreneurship, which are often treated as obvious patterns for action (Polak K., Haber A., 2011). Cultural diversity makes it possible,for example, to partially explain the differences in economic results of post-communist countries (Marody M., Kochanowicz J. 2007).

Entrepreneurial bases, which may be considered as elements of the culture of entrepreneurship, are treated as the driving force for innovative transformations within products and processes (Bratnicki M., Struzyna J., 2001). The most desired type of entrepreneurship - ambitious, developing, using new technologies - leads to innovative solutions. Ambitious entrepreneurship referring to entrepreneurial activities based on innovations constitutes the most important factor for economic development and civilizational progress (Glinka B., Gudkova S., 2011; Cieslik J., 2006). Innovative entrepreneurship refers mainly to transgressive activities in dynamic and risky environment (Strzalecki A., 2011). The analyses of innovative entrepreneurship should thus take into account its cultural determinants (Domurat A., 2011).

It is worth noting that, in literature, there is No full consent in the context of perception of entrepreneurship. For example, P. Drucker (1992) claimed that not every activity connected with risk and the company's development may be described as entrepreneurial. A crucial factor in entrepreneurship consists in creative reaction to changes in the environment or the enterprise. Following Drucker's approach, entrepreneurship is questioned when it is connected with introducing a non-innovative good or service, e.g. opening a repair garage, a commercial company, a new bar or restaurant. Schumpeter also referred the notion of entrepreneurship to very creative activities (creative destruction), being a source of imbalance on the market. Nevertheless, a broad approach dominates in literature, according to which each new market undertaking (e.g. establishing new companies) is an entrepreneurial activity. I. Kirzner (2001) claims that entrepreneurial activities are also those which refer to price competition which do not involve creative destruction and innovativeness. An entrepreneur is, following a broader perspective, an entity discovering new market opportunities.

Entrepreneurial attitudes of citizens are thus crucial for the development of entrepreneurship. They translate into better identification of market occasions, valuation of business ideas, perception of ideas and creative behaviour styles and creativity (Strzalecki A., 2007; Strzalecki A., Domurat A., 2009). An enterprise or work stimulating innovativeness may shape creative attitudes and new behaviours leading to innovativeness. The research conducted in this field by A. Domurat (2011) showed that those who display an entrepreneurial spirit at work, including entrepreneurs and the persons often behaving in an innovative way, manifest a more favourableattitude towards innovative 
business ideas compared to those deprived of the entrepreneurial spirit (full-time employees and those who do not manifest innovativeness at work, respectively). It can thus be suspected that there exists a correlation between entrepreneurial attitudes and the innovativeness of employees which, in turn, translates into the innovativeness of entire economies.

In order to assess the relations between entrepreneurial attitudes among the citizens of European countries and the innovativeness of countries, data published in the Global Entrepreneurship Monitor (GEM) and European Innovation Scoreboard (EIS) was applied.

GEM provides primary data-based measurement and assessment tools of all forms of entrepreneurship. The GEM conceptual framework identifies social, cultural, political and economic contexts in whichindividuals express their intentions and perform their entrepreneurial activities. Entrepreneurial attitudes were measured with the use of four factors, including:

1) entrepreneurial intentions, which means the percentage of the population aged between 18 and 64 years (individuals involved in any stage of entrepreneurial activity excluded) who are latent entrepreneurs and who intend to start a business within three years;

2) perceived opportunities, which means the percentage of the population aged between 18 and 64 years who see good opportunities to start a firm in the area where they live;

3) perceived capabilities - the percentage of the population aged between 18 and 64 years who believe they have the required skills and knowledge to start a business;

4) fear of failure -the percentage of the population aged 18-64 years perceiving good opportunities who indicate that a fear of failure would prevent them from starting up a business.

The factor used to reflect the level of innovativeness of countries wasthe Summary Innovation Index (SII). The overall performance of each country's innovation system has been summarised in this composite indicator. The results of SII are published by the European Innovation Scoreboard (EIS), which uses the most recent statistics from Eurostat and other internationally recognised sources available at the time of analysis. International sources have been used in the reports wherever possible in order to ensure comparability between countries (European Innovation Scoreboard, 2018). The coefficients used for assessing the correlations between analysed variables were thePearson correlation coefficient together with the $\mathrm{R}^{2}$ coefficient constituting the measure of model adaptation quality, showing what percentage of one variable explains the changeability of the other variable. Its value is from 0 to 1.

Entrepreneurial intentions were the first entrepreneurial attitudeanalysedin relation to the innovativeness of countries. The results of analysis referring to the relation between entrepreneurial intensions and Summary Innovation Index (SII) demonstrated that there exists a moderate negative correlation $(r=0.55)$ between these variables. This means expressing weaker entrepreneurial intentions by the countries characterized by higher innovativeness indicator (Fig. 1). This confirms a general trend observed in all countries around the world, where the desire to become an entrepreneur generally decreases together with reaching a higher development phase (Global Entrepreneurship Monitor Polska, 2015). The observed correlation should not be treated as an absolute rule, as the citizens of some countries with similar SII coefficient are characterized by a diversified level of entrepreneurial intensions. For example, relatively strong entrepreneurial intensions are observed in Germany, characterized by high SII coefficient. Among European countries, the highest level of entrepreneurial intensions is observed in Romania, which alsoshows the lowest SII, which confirms the negative relationship between the analysed variables. 


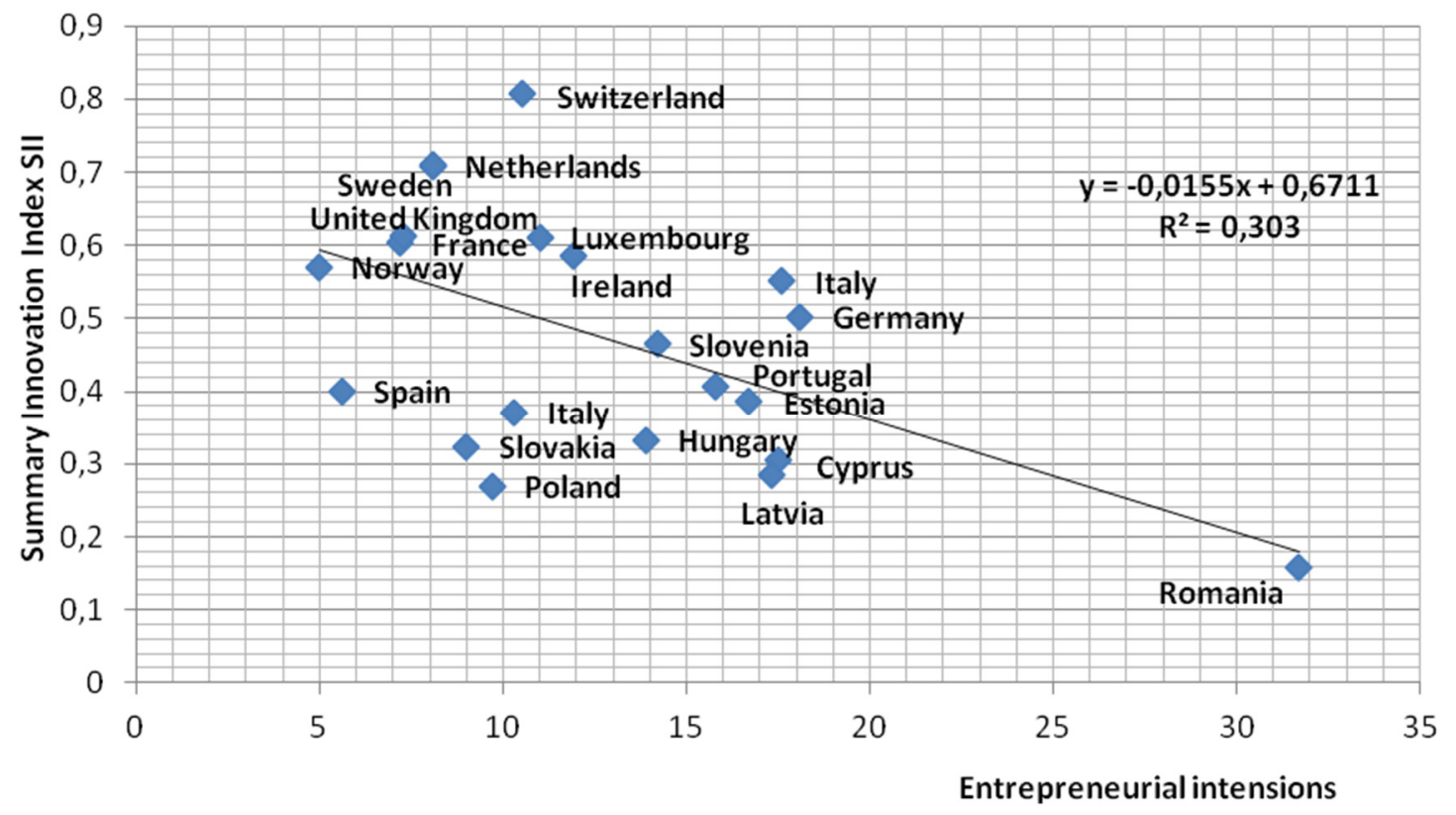

Source: author's calculations based on Global Entrepreneurship Monitor 2017/2018, European Innovation Scoreboard 2018

Fig. 1. Correlation between entrepreneurial intensions and Summary Innovation Index (SII)

Another element of the analysed entrepreneurial attitudes is perceived opportunities, referring to the percentage of the population aged between 18 and 64 years who see good opportunities to start a firm in the area where they live. It was observed that in European countries, together with the increase in SII, perceived opportunities to start a firm are also higher (Fig. 2). This correlation is reflected in the value of the Pearson coefficient $r=0.50$.

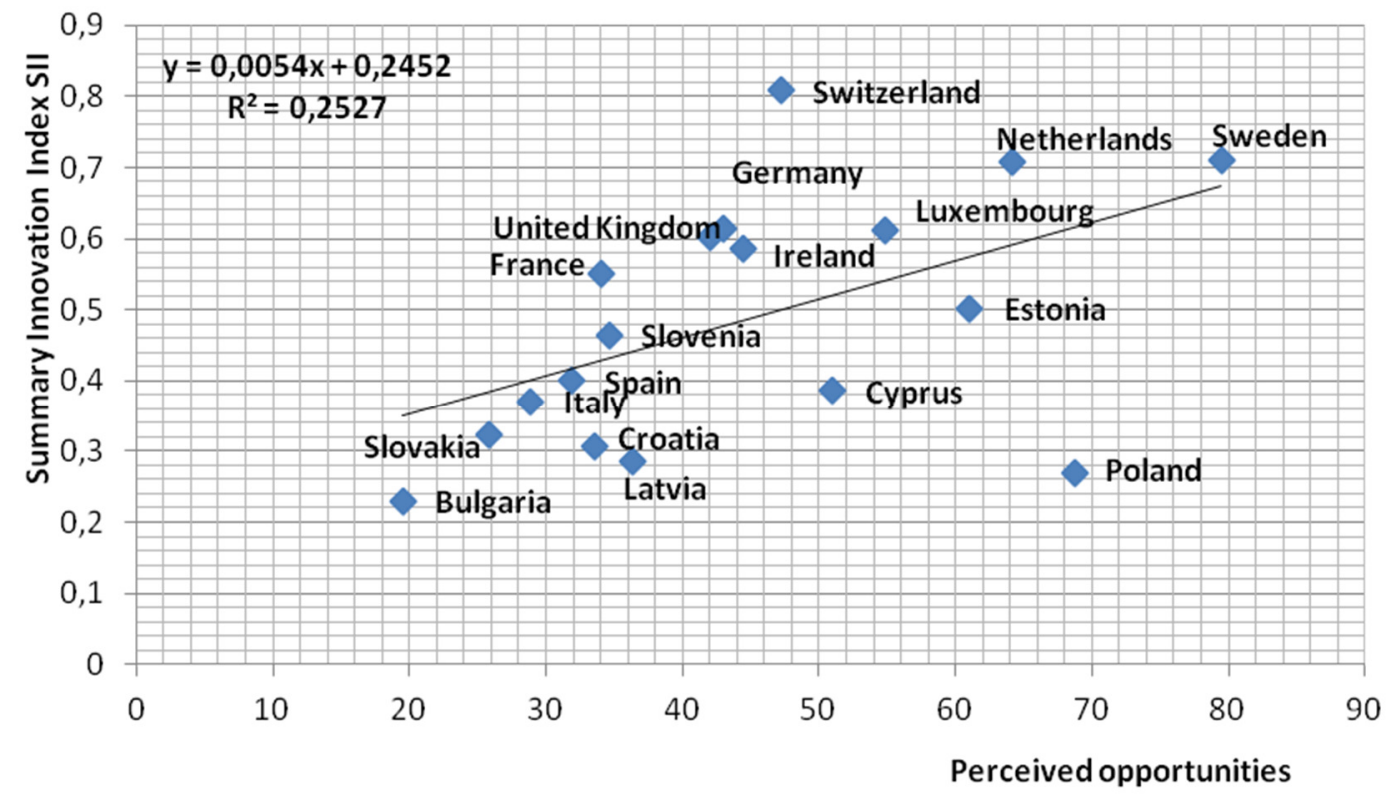

Source: author's calculations based on Global Entrepreneurship Monitor 2017/2018, European Innovation Scoreboard 2018

Fig. 2. Correlation between perceived opportunities and Summary Innovation Index (SII)

Sweden, a country with one of the highest SII values, has the highest number of inhabitants who noticedan opportunityto start a firm. Poland constitutes a certain exception here, as it has a relatively low SII value compared to the perception of opportunities to start a firm. It can thus be assumed that noticing development opportunities for a new firm in this country constitutes an element of the 
entrepreneurial base supporting the establishment of new entities. It is worth noting that when not taking Poland into account in analysing the interdependencies, the correlation coefficient would be moderately high and would amount to $r=0.70$. In the European countries, the lowest SII value together with the weakest perceived opportunities, was observed in Bulgaria.

Another element reflecting entrepreneurial attitudes- perceived capabilities - determines the percentage of population aged between 18 and 64 years who believe they have the required skills and knowledge to start a business. The relation of these attitudes expresses a weak negative correlation ( $r=-0.32)$ with the level of innovativeness in the countries (Fig. 3). This means that the citizens of countries characterized by higher SII value assess their skills and knowledge to start a business less positively. It is possible that the markets in these countries are more mature, and the citizens adopt a more critical approach towards their skills and knowledge in connection with starting a new undertaking. It is, however, necessary to observe that differences are not high between the citizens of European countries in considering perceived capabilities. The citizens of Slovenia and Poland assess their skills the most positively, while the most negative assessment is attributed to the inhabitants of Italy.

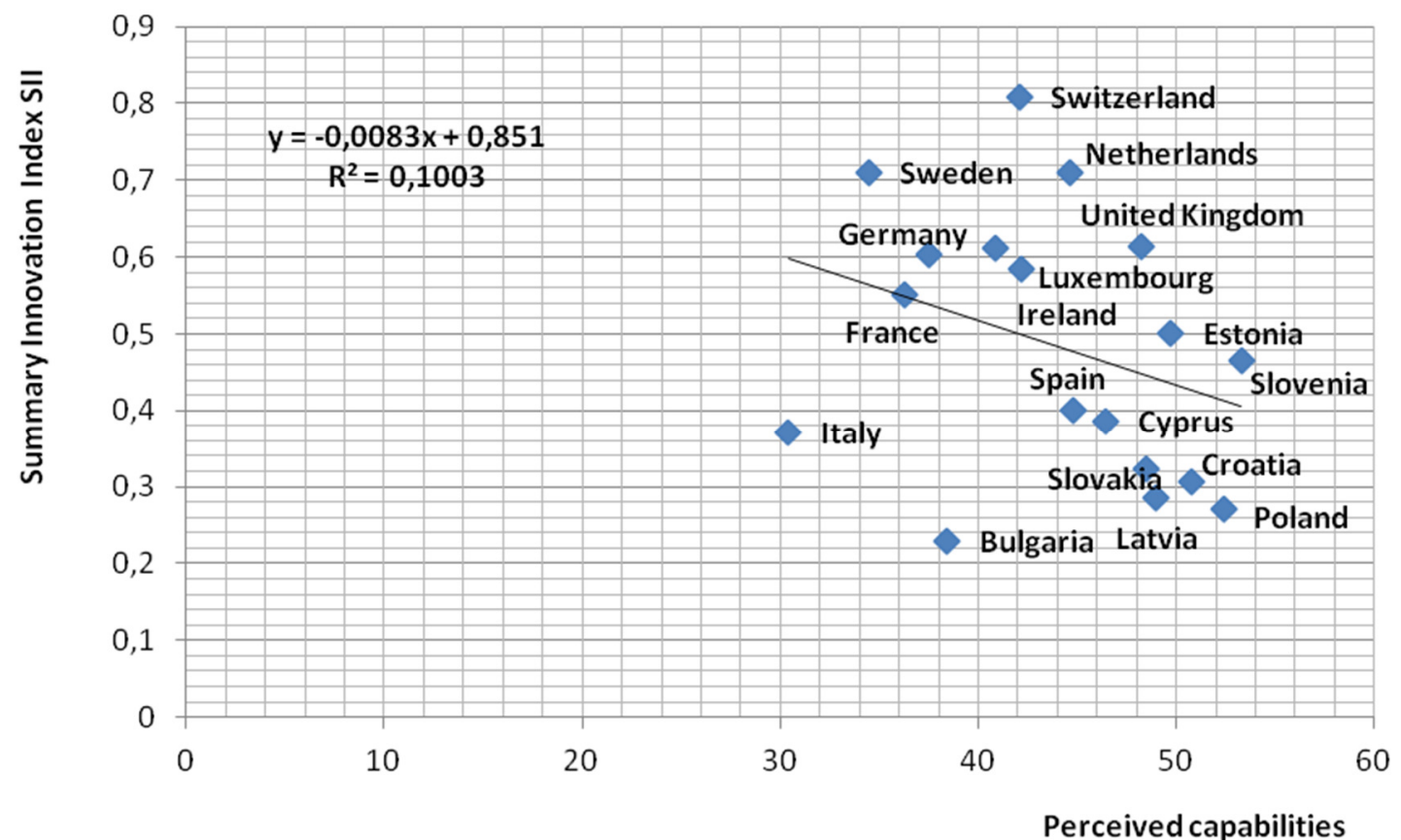

Source: author's calculations based on Global Entrepreneurship Monitor 2017/2018, European Innovation Scoreboard 2018

Fig. 3. Correlation between perceived capabilities and Summary Innovation Index (SII)

For the last of the analysed entrepreneurial attitudes - the fear of failure - No correlation was reported between it and the level of innovativeness measured using SII $(r=0.00)$. It can thus be assumed that perceiving a fear of failure does not depend on the innovativeness of economies (Fig. 4).

The citizens of Cyprus and Italy express the highest fearof failure in connection with a new undertaking, while it is the lowest among the citizens of Bulgaria. Nevertheless, even if the Bulgarians are not afraid to fail, they do not perceive the opportunity to start a new firm in their area of living. A relatively low fear of failure is demonstrated by the citizens of such countries as Switzerland and the Netherlands and their SII value remains high. 


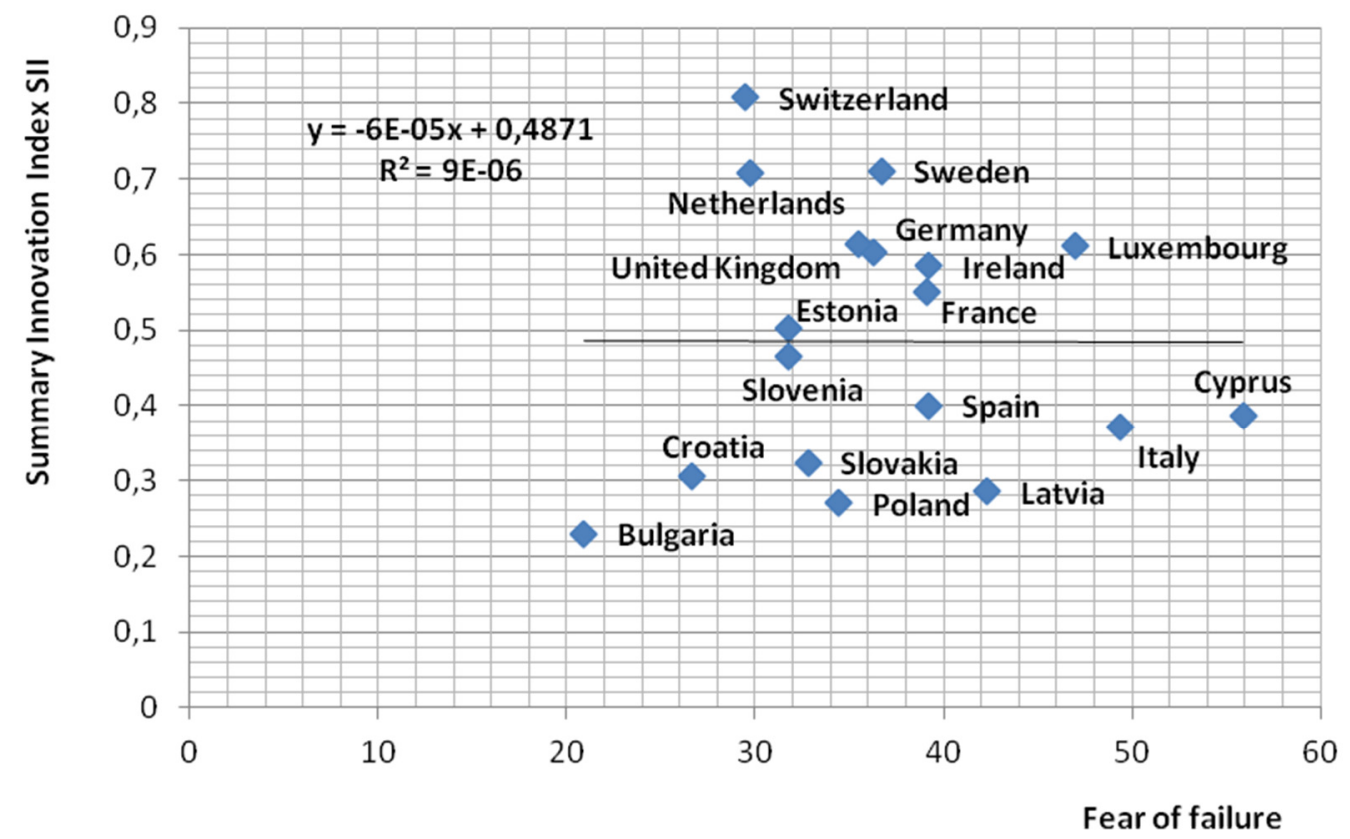

Source: author's calculations based on Global Entrepreneurship Monitor 2017/2018, European Innovation Scoreboard 2018

Fig 4. Correlation between fear of failure and Summary Innovation Index (SII)

\section{Conclusions, proposals, recommendations}

The analysis performed referred to relations between entrepreneurial attitudes of the citizens of European countries and the level of innovativeness of economies. Based on the conducted empirical research, the following conclusions were formulated.

1) The citizens of countries characterized by higher innovativeness coefficient express weaker entrepreneurial intensions (intension to start a business within three years). This may result from many different factors, among which the crucial factor is probably greater attractiveness of remunerated employment in these countries compared to less-developed countries, characterized by a lower level of innovativeness.

2) It was found that in the European countries, together with the increase in SII value, the percentage of the population who see good opportunities to start a new firm in the area where people live (perceived opportunities) is also high. It can thus be claimed that conditions resulting from the economic, institutional and legal environment in these countries are more favourable for entrepreneurship and (at the same time) innovativeness, in comparison to the countries is characterized by lower level of innovativeness. At the same time, paradoxically, as it has been mentioned in the previous point, in more innovative countries, in spite of a stronger perception of the opportunities to start a new firm, weaker intentions to start a business were recorded.

3) It was also demonstrated that the citizens of countries characterized by higher SII value assess their skills and knowledge to start a business more critically, which probably has a negative impact on the intensions of the citizens of these countries to start a business.

4) Based on the conducted analysis, it can also be stated that the perceived fear of failure does not depend on the level of innovativeness of economies.

5) An important premise for economic policies of countries characterized by a lower innovativeness coefficient resulting from the conducted research involves the necessity to take into consideration the factors shaping entrepreneurial attitudes, particularly those connected with the perception of the opportunities to start a business. This is connected with the shaping of 
institutional and legal (as well as economic and cultural) conditions favourable for entrepreneurship, which are the bases for entrepreneurship, including innovative entrepreneurship.

\section{Bibliography}

1. Baker, W.E., Sinkula, J.M. (1999). Learning Orientation, Market Orientation, and Innovation: Integrating and Extending Models of Organizational Performance; Journal of Marketing Focus. Management; 4 (4), pp. 295-308.

2. Berger, B. ed. (1994). Kultura przedsiebiorczosci (The culture of entrepreneurship). Warszawa: Oficyna Literatow "Roj".

3. Bratnicki, M., Struzyna, J. (2001). Przedsiebiorczosc i kapital intelektualny (Entrepreneurship and intellectual capital). Katowice: Wydawnictwo Akademii Ekonomicznej w Katowicach,.

4. Cieslik, J. (2006). Przedsiebiorczosc dla ambitnych. Jak uruchomic wlasny biznes (Entrepreneurship for ambitious individuals. How to launch your own business). Warszawa: Wyd. Akademickie i Profesjonalne.

5. Dimitratos, P., Voudouris, I., Plakoyiannaki, E., Nakos, G. (2012). International Entrepreneurial Culture Toward a Comprehensive Opportunity-Based Operationalization Of International Entrepreneurship; International Business Review; Vol. 21, s. 708-721.

6. Domurat, A. (2011). Przedsiebiorczosc a kreatywnosc $i$ innowacyjnosc (Entrepreneurship versus creativity and innovativeness). [in], Innowacyjna przedsiebiorczosc-teorie, badania, zastosowania praktyczne, perspektywa psychologiczna, A. Strzalecki, A. Lizurej (ed.). Warszawa: Wyd. Academica.

7. Drucker, P. F. (1992). Innowacja i przedsiebiorczosc - praktyka i zasady (Innovation and entrepreneurship - practice and rules). Warszawa: PWE.

8. European Innovation Scoreboard 2018. Retrieved: https://ec.europa.eu/growth/industry/innovation/factsfigures/scoreboards_en. Access: 15.01.2019.

9. Glinka, B. (2008). Kulturowe uwarunkowania przedsiebiorczosci w Polsce (Cultural determinants of entrepreneurship in Poland). Warszawa: PWE.

10. Glinka, B., Gudkova, S. (2011). Przedsiebiorczosc (Entrepreneurship). Warszawa: Wyd. Wolters Kluwer Polska.

11. Global Entrepreneurship Monitor 2017/2018. Retrieved: https://www.gemconsortium.org/report. Access: 15.01.2019.

12. Global Entrepreneurship Monitor Polska 2015. http://www.pi.gov.pl/PARPFiles. Access: 17.10.2018.

13. Gomez-Haro, S., Aragon-Correa, J.A., Cordon-Pozo E. (2011). Differentiating The Effects of The Institutional Environment On Corporate Entrepreneurship, Management Decisions 49 (9/10), pp. 1677-1693.

14. Gupta, V., MacMillan, I.C., Surie, G., (2004). Entrepreneurial Leadership: Developing and Measuring a Cross Cultural Construct, Journal of Business Venturing 19 (2), pp. 241-260.

15. Kirzner, I. (2010). Konkurencja i przedsiebiorczosc (Competition and Entrepreneurship). Warszawa: Wyd. FIJORR.

16. Kwiatkowski, S. (2000). Przedsiebiorczosc intelektualna (Intellectual Entrepreneurship). Warszawa: Wyd. Nauk. PWN.

17. Marody, M., Kochanowicz J. (2010). Kultura i Gospodarka (Culture and Economy). Warszawa: Wyd. Naukowe Scholar.

18. Polak, K., Haber, A. (2011). Polskie spojrzenie na przedsiebiorczosc (A Polish perspective of entrepreneurship), Harvard Business Review Polska, 11, pp. 25-27.

19. Strzalecki, A. (2007). Tworcza przedsiebiorczosc i zarzadzanie. Wyniki nowych badan psychologicznych (Creative entrepreneurship and management. Results of new psychological studies);

Prakseologia(Praxeology), 147, pp. 163-188.

20.Strzalecki, A. (2011). Style tworczego zachowania $w$ przedsiebiorczosci (Creative behaviour styles in entrepreneurship), [in] Innowacyjna przedsiebiorczosc. Teorie, badania, zastosowania praktyczne, perspektywa psychologiczna (Innovative entrepreneurship. Theories, research, practical applications, psychological perspective); Strzalecki A. ed., Lizurej A. Warszawa: Wyd. Academica SWPS.

21.Strzalecki, A., Domurat, A. (2009). Model Stylu Tworczego Zachowania a poziom innowacyjnosci przyszlej pracy studentow (Behaviour vs. the level of innovativeness of the students' future job); Czasopismo Psychologiczne (Psychological Magazine), 15 (1), pp. 141-152.

22. Wai, H., Yeung, C., (2002). Entrepreneurship in International Business: An Institutional Perspective; Asia Pacific Journal of Management; 19 (1), pp. 29-61. 